\title{
FLASH TEMPERATURE FOR W/N CIRCULAR ARC GEARS
}

\author{
Ahmed M. M. El Bohloul \\ Assoclale Professor, Faculdy of Englneering. \\ Mansowa universily. Maisoura, ECYPT.

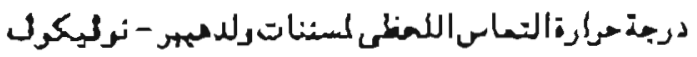

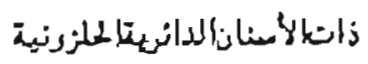

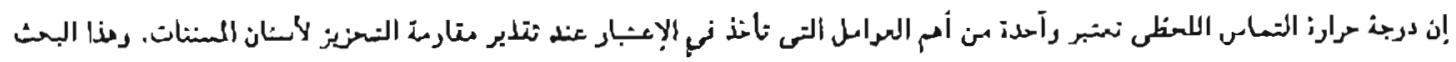

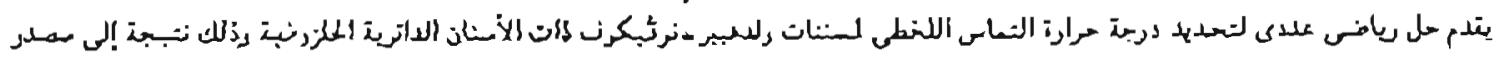

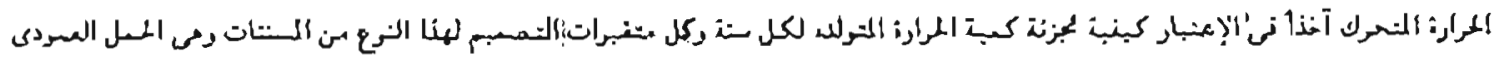

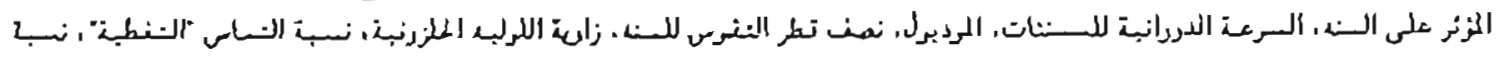

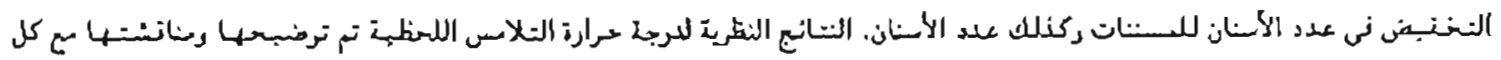

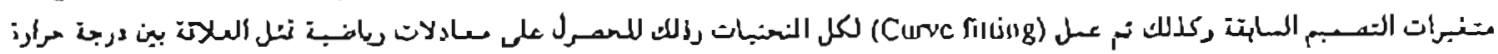

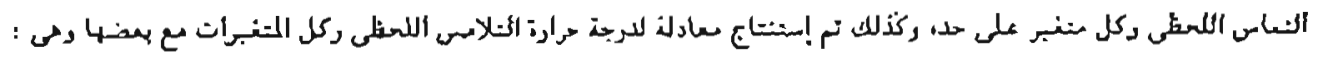
$\theta / 11=C P 0.9725 \cdot N^{0.389} \cdot m^{0.968} \cdot p^{0.994} \cdot C^{0.706} \cdot p^{0.193}$

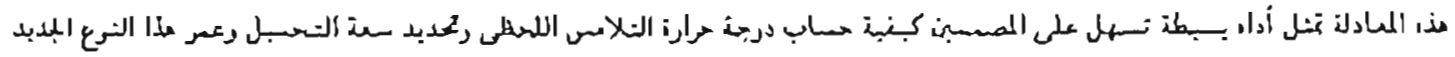

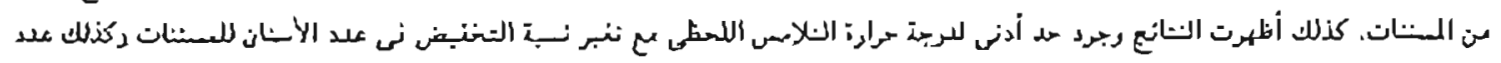

\section{ABSTRACT}

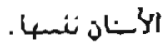

Mic Rash lemperature ts one of Ute inportan faclors for evaulating the scoring reslstance of the gear leetlt. in the present paper. a numerical'solulton of the flash temperalure for $\mathrm{W} / \mathrm{N}$ chcular - arc gear due lo mouing heal source is done lateing inlo account the partitioning of the heat in the contact zone to each looll and all the varables for llue design of this lype of gears. Tooll load speed of rotation, module. radii of curwalure, helix angle. gear ralio. number of tccll and conlact ratio are considered. The theorelical resulis of the flash iemperature are presented and discussed wilh the above cartables. A curve fillug of the results is done aitd the folluing fornula derlved for the Rash leniperature

$\theta / \mu=C p^{0.9725}$. No.389 $\cdot m^{0.968} \cdot \rho^{0.991} \cdot$ CR0.706 $\cdot \beta^{0.193}$

This fommla represents a simple lool for the designer lo calculate the fasil teniperature the carresponding load carying capaclly and life of live gear are delcmived. T7ue stidy also slwows that there is a certain minumul value for the hash Lemperalure with live cliange of the gear ratio.

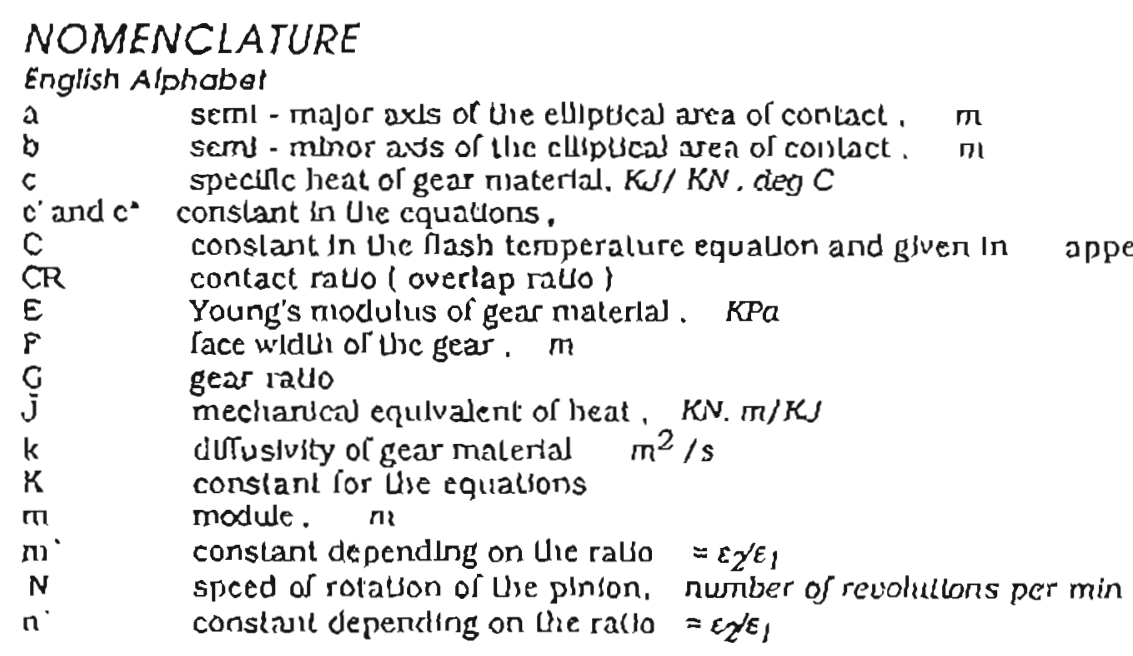




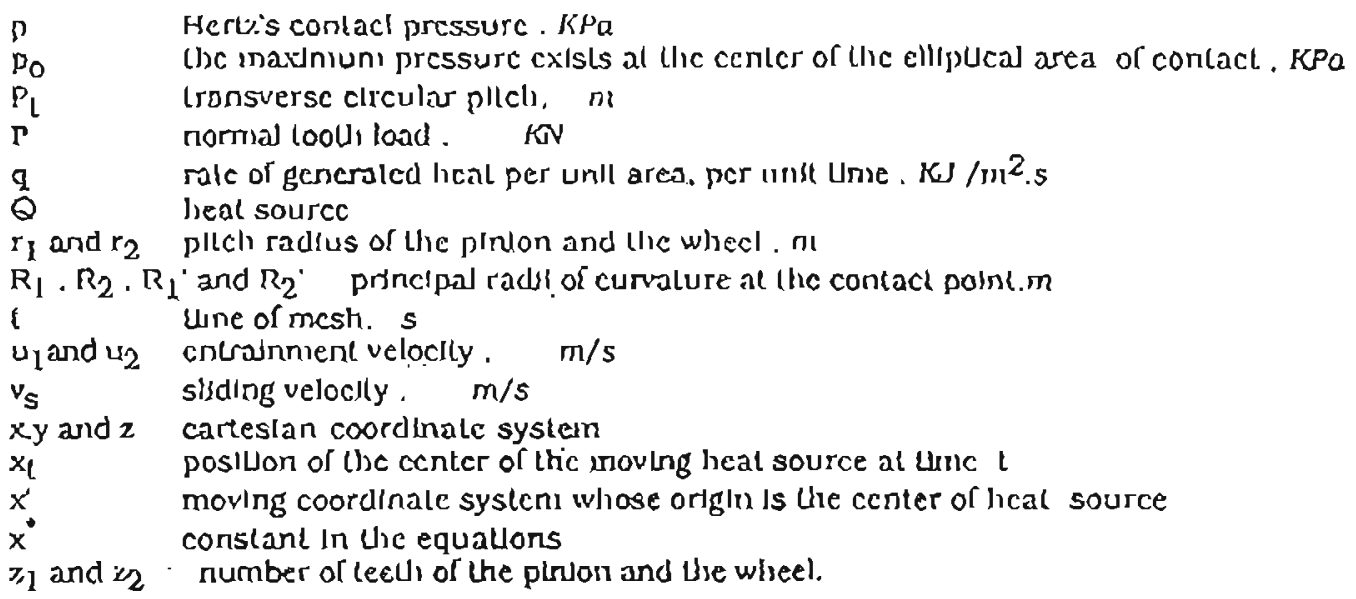

\section{Greek Alphabel}

a pressure angle degree

B hellx angle, domree

ispecific weight of gear material. $\mathrm{Kg} / \mathrm{m}^{3}$

$\varepsilon_{1}$ and $\varepsilon_{2}$ rools of the quadralle equaton defining the conlact surfaces

$\eta \quad$ constant in the equaUons

- (3as) temperature. oC

$\lambda \quad$ constant in the cquations

$\mu \quad$ coefficlent of iricuon

u Polsson's ratio of Une gear materlal

$\xi \quad$ constant in the cquations

$p_{1} \quad$ proßle radus of Uic pinlon looth, m

$\rho_{2}$ prolle radlus of the wheel tooth. $\mathrm{m}$

$\Delta p \quad$ musmatch in radius of curvature of the coolh pronies of the plition and of the whect in Uansverse planc,

$\$$ coeflelent of local parutuon of heat

$\Psi$ anglc between the planes containlng the inaxlmum or the minhmum principal radlus of

W) auxllary angle dependent on $\varepsilon_{1}$ and $\varepsilon_{2}$

(1) angular veloclly or uic gear rad/s

\section{INIRODUCIION}

Gear systeins are being used more frcquently at high spiced and heavy load, and scortng resistance of gears has become an Imporlant faclor in evalwallng their strength. Generally. scorlng is considered to be rclaled to the instantaneous temperature rise on looth surface caused by irlclional heat. and (his concepl of nasl) (emperalure is recomrnended by AGALA 217.01 as the most rellable means 10 determine the scor ing reslsturice. The tolal lemperature in the contact is the sum of the bulk lemperature of the gear and the nash temperalure.

The first theorclical study on the Rasb temperature caused by friction between livo bodies was done by Blok in (1937). He assumed one-dimensional heat fow whlch leads to a simple and chiclent approxinate equalion on nash lemperalure. $\Lambda$ sinnilar study was also done by Jaeger (1942).

More delajled studics were donc by Holm (1948). Bowden and Tabor (1950), and Nakada and tashimoto (1963). Arcliard (1958-1959) has also referred to bolh clastic and plastle contact. The mos! recent sludies ivere made by Symun) (1967) who decermalned Uje fash temperalure and partIUon of gencraled heat between livo rubbing bodics numerlcally. Tobe and Kato (1974) examlned unstcady conclitions In line conlacts in whilch Uie Inlenslly and veloclity of thie moving heat source change Instantancously at It moves (lirough U) contact. Terachl and Morl (1974) col.sldered effects of dynanic load on Sash temperalure under the Inhuence of diflerent load - speed condllions

Roylance and Alkaleb (1987) delemined the surface lemperalurc components. bulk and nasl? lemperalures. during a lour - ball operallon . 
The inoln purpose or the present worle is to decennlie the fomizula of the hash lemperalure of (lise

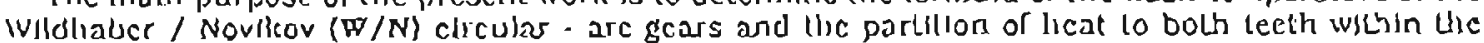

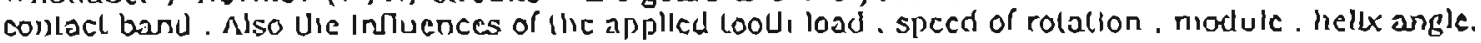
radll of curvalure gear rallo. number of fecti and combat rallo are sludicel.

\section{ANALYSIS OF THE FLASH TEMPERATURE ON W/N CIRCULAR - ARC GEARS}

1- W/N Cheular - Are Gears:

Wliohaber Nov(kov (W/N) clrcular-are gears are conformal gears of convex concave cooth profllc in transverse plane and convex convex tooth proflie in axlat plane : Contact is lieorelleally at a polnt, whlch under load becomes an ellipse. The ellipucal area of conlact moves in adal discclion along the tooth face at a fuxed height above the rool of the lecti as sliown In Fig (I).

\section{2 - Flash Temperalure Equalions :}

Lel Uie $x$-axls be the moving djection of the elipsoldal heat source. $y$-axs along the tooth helght. The $x$-aus towards the inside of a sems-Inilnile body, and the surface of the lceti are $7,=0$. The rate of heal $q$ gencraled per unll aren in unll tume distribulcs from $x=-a 10 x=a$, and $y=-b 10$ $y=b$. The heal source is assunied to move along the looth face in $x$-direction .

The quantily of the heal source is glven by the Herian clasuc conlacl slress $P(x . y)$. sliding velocity between gear lcelli $\mathrm{v}_{\mathrm{g}}$ and the coefiticient of frictiony.

$q(x, y)=1 / \bar{J} \quad \mu \quad p(x, y)\left|v_{g}\right|$

Consider llic case where Uie heal source moves on Ule surface of the seni - ininile body, and assume Uie bulk lemperalure to be zero. When a heat source $Q$ is glven on the surface $x=\bar{\lambda}$, y=y al ume $l=\bar{l}$. - Wie lemperalure 0 al polnt $(x, y, z)$ and al $u n c l=l$ is expressed in the fonn

$$
\theta=\frac{Q}{2 \pi \gamma c k(t-\bar{t})} \exp \left\{-\frac{(x-\bar{x})^{2}+y^{2}+z^{2}}{4 k(t-\xi)}\right\}
$$

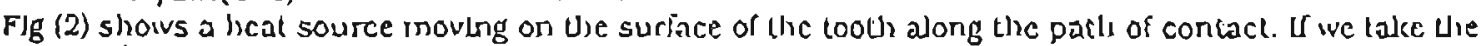
center of the elupsoldal heal source at thic slaring of meshing $(l=0)$ as the origin or the $x$. axts. Uic center ivill be al $x=x_{t}$ at $t=l$. Using cqualion (2), Lhe icmperalure of lise point $P(x, y, z)$ at $t=l$ is oblalned by sunvmallois of lemperature rlse caused by the heal source $q$ ds dy di al each instant fiom $t=0$ to $t=t$

$\theta(x, y, z, l)=\frac{1}{2 \pi y c k} \int_{0}^{1} \frac{d \bar{t}}{1-T} \int_{x_{1}-a}^{x_{1}+a} \int_{y_{1}-b}^{y_{1}+b} q\left(\bar{x}-\bar{x}_{1}, y_{1} \bar{i}\right)$ e $x \rho\left\{-\frac{(x-\bar{x})^{2}+y^{2}+z^{2}}{4 k(1-t)}\right\} d y d \bar{x}$

The surface temperalure at the pount $p(x, y)(z \times 0)$ al Ume $t=t$

$\theta(x, y, i)=\frac{1}{2 \pi y c k} \int_{0}^{1} \frac{d i}{1-i} \int_{x_{1}-a}^{x_{1}+a} \int_{y_{1}-b}^{y_{1}+b} q\left(\bar{x} \cdot \bar{x}_{1}, y_{1} i\right) \exp \left\{-\frac{(x \cdot \bar{x})^{2}+y^{2}}{4 k(1-i)}\right\} \cdot d y d \bar{x}$

Introducing tie following new varlables duc 10 an bilaginary singular point at tal

a. Let $\lambda=\langle 1 \cdot \bar{i})^{1 / 2}$, then $d \bar{i}=-2 \lambda d \lambda$.

o. Let $\quad \xi=\frac{x-\bar{x}}{\sqrt{4 \mathrm{k} \lambda}}$, then $d \bar{x}=-2 \sqrt{k} \lambda d \xi$,

c. Let $\quad \eta=\frac{y}{\sqrt{4 x \lambda}}$ then $d y=-2 \sqrt{k} \lambda d \eta$

By substiuluig these variabies in the cqualion (1) and deteriting the لymils or inlegrations. we can obtaln Uie rollowing equation

$\xi_{u}=\frac{x-x_{1}+a}{2 \sqrt{k} \lambda}, \quad \xi_{1}=\frac{x-x_{1}-a}{2 \sqrt{k} \lambda}$

$n_{u}=\frac{y_{1}+b}{2 \sqrt{k} \lambda} \quad \eta_{1}=\frac{y_{1}-b}{2 \sqrt{k} \lambda}$

$\therefore \theta(x, y, t)=\frac{4}{\pi y c} \int_{0}^{\sqrt{1}} \lambda d \lambda \int_{\xi}^{\xi_{u}} \int_{\eta_{1}}^{\eta_{u}} q\left(x-\bar{x}_{1}-2 \sqrt{k} \lambda \xi, 2 \sqrt{k} \lambda \eta, 1-\lambda^{2}\right) \exp \left\{-\left\langle\xi^{2}+\eta^{2}\right\rangle\right\} d \eta d \xi$

if $q$ is live ralc of generaled heat between lise conlacung teeth and $\$$ is Uic local partiuon of heal. Uic $\phi q$ is lise ainount of heat nowing lillo toolh 1 (pluton) and llic remoluder $(1-\phi) q$ 
M. 71 Nhmed M. M. El Bolinul
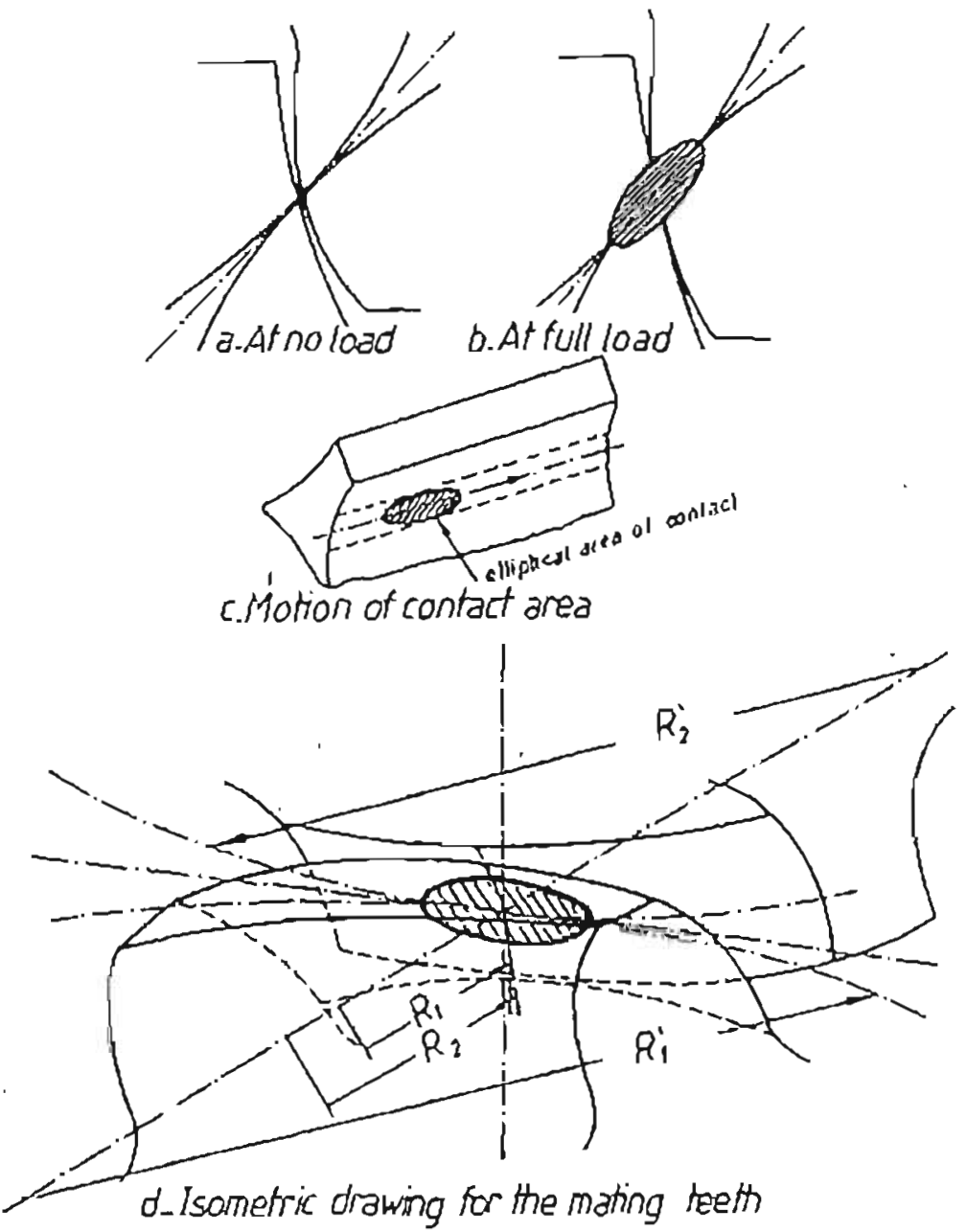

Fig(1) Geomeiry of heeth profiles before and after loading

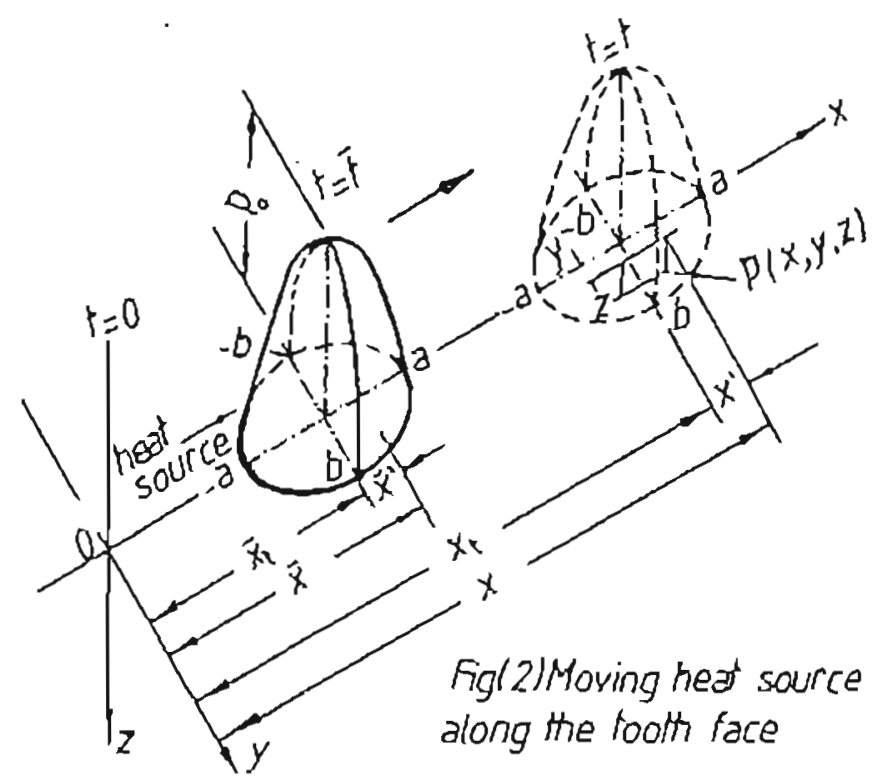


nows into loolh 2 lwheel). Then the surface (cmperaiure rises of two (ectli arc oblalned fron equation (5) as

$O_{1}(x, y, 1)=\left[\frac{4}{\pi \gamma C} \int_{0}^{\sqrt{1}} \lambda \delta \lambda \int_{\xi_{1}}^{\xi_{u}} \int_{\eta_{1}}^{\eta_{u}} \phi q e \times p\left[-\left\langle\xi^{2}+\eta^{2}\right)\right\} d \eta d \xi\right]_{1}$

$\theta_{2}\langle\dot{x}, y, t\rangle=\left[\frac{4}{\pi y c} \int_{0}^{\sqrt{1}} \lambda d \lambda \int_{\xi_{1}}^{\xi_{u}} \int_{\eta_{1}}^{\eta_{u}}(1-\phi) q \exp \left\{-\left(\xi^{2}+\eta^{2}\right)\right\} d \eta d \xi\right] 2$

where $x^{4}-x \cdot x_{l}$

The surface tempcralures of both bodies are requlted to be cqual al cach point in contacl. The bulk tempcratures of boun bodies arc assumed to be zcro. so the unposed condluon is

$$
\theta_{1}\left(x^{\prime}, y, t\right)=\theta_{2}(x, y, t)
$$

over the contact band. Tlis equatson deternines Uic unkrown functson $\phi$.

\section{3-5eml - Major and Seml - Minor Axes of the Ellollicol Arod ol Conloct:}

Tlie clipUcal arca of contact is a funcuon or Jie geometn' of the surfaces in contact. Uhe clasue constants of the matertal of the gears and Uje nomid load on Uie gear tecth. The semb - major and seml. minor aves of the elipse are obtancd from Herz's conlact stress cquallons. The lollowing equations for the pruiclpal radll of curvature of flic suffaces at lic conlacl point are oblabned. if $\Delta \rho$ Is considered; $\Delta p=\left(\Omega_{2}-R_{1}\right)$

$R_{1}=\rho_{1}=c i m=\rho$

$A_{2}=\rho_{2}=c \rho_{1}$

$R_{1}=\frac{r_{1}(1+\tan \beta \cdot \cos \alpha)^{3 / 2}}{\tan ^{2} \beta \cdot \sin \alpha\left(1+\sin \alpha \cdot r_{1} / \rho_{1}\right)}$

$\mathrm{A}_{2}=\frac{r_{2}(1+\tan \beta \cdot \cos \alpha)^{3 / 2}}{\tan ^{2} \beta \cdot \sin \alpha\left(1-\sin \alpha \cdot r_{2} / \rho_{2}\right)}$

The rools $\varepsilon_{1}$ and $\varepsilon_{2}$ of the quadralic equallon definsng lic ellipucal arca of contacl, are dependent on $R_{1}, R_{2} . R_{1} \cdot R_{2}$. and the angle $\psi$ belween the planes containing the niaxinum or nindmum prinespal radil of curvalure and are glven by Use following equalions

$\varepsilon_{1}=\frac{1}{2}\left[\frac{1}{R_{1}}+\frac{1}{R_{1}^{*}}+\frac{1}{R_{2}}+\frac{1}{R_{2}^{\prime}}\right]$

$E_{2}=\frac{1}{2}\left[\left(\frac{1}{\mathrm{R}_{1}}-\frac{1}{\mathrm{~A}_{1}^{\prime}}\right)^{2}+\left(\frac{1}{\mathrm{R}_{2}}-\frac{1}{\mathrm{~A}_{2}^{\prime}}\right)^{2}+2\left(\frac{1}{\mathrm{R}_{1}}-\frac{1}{\mathrm{H}_{1}^{\prime}}\right)\left(\frac{1}{\mathrm{R}_{2}}-\frac{1}{\mathrm{R}_{2}^{\prime}}\right) \cos 2 \psi\right]^{0.5}$

For IVildhaber - Novikov gears. $\psi=0$

$\varepsilon_{1}$ and $e_{2}$ are relaled by lic auxlliary angle $\psi_{1}$. given by $\psi_{1}^{\prime}=\cos ^{-1}\left(\varepsilon_{2} / E_{1}\right)$

From the values of $\Psi_{1}$, Uic constanls ri and ri in (he fo)lowang cquatons are obtained (Roark. 1965: Tumoshenko and Coodier, 1984)

$a=m\left[\frac{1.5 P A}{e_{1}}\right] i s$

$b=n^{\prime}\left[\frac{1.5 P A_{1}}{E_{1}}\right] 1 / 3$

$A=\frac{1}{2}\left[\frac{1-v_{1}^{2}}{E_{1}}+\frac{1-v_{2}^{2}}{E_{2}}\right]$, ror (lie sunc materid $A=\frac{1-v^{2}}{E}$

\section{Conlacl Piessure Dislribulion:}

According to Hertz. We intensily of pressure. p. over lile surface ol contact is represcnted by vic ordlnaics of a scru - elipsold consincted on the surface of conlact. Uius 
$p=p_{0} \sqrt{1 \cdot \frac{x^{2}}{a^{2}}-\frac{y^{2}}{b^{2}}}$

The inaximum pressure ( $p_{0}$ ) exists at the center of the surface of conlact. Since the total toolli load P. is cqual to line volume of the scml - ellipsold.

$\mathrm{P}=\frac{2}{3} \pi \mathrm{a} b \mathrm{p}_{\mathrm{o}}$

From (1)ls expression the maximum pressure. $p_{0}$ is found to be

$p_{0}=1.5 \frac{P}{\pi a b}$

5 - Sliding and Enlrainment Velocilies:

According to Dyson. Evans and Snlelle (1986) Uhe entralnment veloclty is Uhe mean of the surface velocilies relative to tie point of contact; thus

$u_{1}=\omega s\left(\cot ^{2} \beta+\cos ^{2} \alpha\right)^{1 / 2}$,

$\left.\mathrm{u}_{2}=\frac{\omega}{2}\left(1-G^{\cdot 1}\right)\left(\rho_{1}-x^{*}\right)-\omega r \sin \alpha\right)$

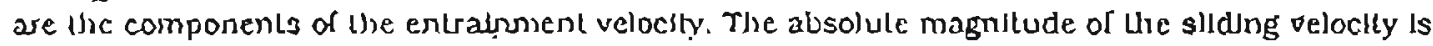

$v s=\omega\left(1-G^{-1}\right)\left(\rho_{1}-x^{*}\right)$

6- Time ol Meshing: (Fig(3-a))

Contact rallo for $\mathrm{W} / \mathrm{N}$ circular - are geais is equal to toolli advance / transucrse circular plicir

$C R \cdot \rho_{1}=F(a) \beta$

By dividing the equation (23) by the vaclocity

$C R \cdot t_{p}=t_{l}$

$t_{P}=1$ me of meshing for slugle pair $=1 / \mathrm{Nz}$

$l_{l}=$ tolal lime of meshing = Ume of mesbing for single padr + colal llase of meshing for double palr (2t')

$C R \cdot t_{p}=t_{p}+2 t^{*}$

$\therefore 2 t^{*}=C R \cdot t_{p} \cdot t_{p}=1 / N_{z}(C R-1)$

Therr, ume of meshing for a double pair in contacl al Uic start or cuel of contact is .

$t^{*}=1 / 2 \mathrm{Nz}(\mathrm{CR}-1)$

and Uie lime of mesiling at any zone of conlact ls given in Fig (3 -b).

\section{CALCULAIION OF THE FLASH JEMPERATURE}

The Insh Lemperalure on W/N clrcular-anc gear lcelin caused by friclional heat can be oblained by substutu(jng Uie equatuons (1).(16). (17).(18). (22) and (24) 10 equalions (6) and(7) and then relating equaton (8). This solution is found rumerically. The mesling Ume is divided into short intervals $\Delta t$ arld the unkjown funclion $\phi$ is detcringed step by step) from $t=0$ to any (trme tal: that is . In the case of $l=j \Delta t \quad U=1,2,3 \ldots . .$. . equation $(G)$ for plnton can be approxlanated in the following polymominals (Chemey and K(ncald (1980) and Gcrald (1978)).

$\theta_{1}\left(x^{\prime}, y, j \Delta t\right)=\left[\frac{2}{\pi \gamma c} \sum_{r=1}^{j}\left(\left(K_{r-1}+K_{r}\right)(\sqrt{r \Delta t}-\sqrt{(r-l) \Delta t})\right)\right]_{1}$

$\left[K_{r}=4 \int_{0}^{\xi_{u}} \int_{0}^{\eta_{u}} \sqrt{(j-r) \Delta t} \phi(\ddot{x}, y,(j-r) \Delta l\} q\{\ddot{x}, y,(j-r) \Delta l\} \exp \left(-\left(\xi^{2}+\eta^{2}\right)\right\} d \eta d \xi\right]_{1}$

$\left[K_{0}=4 \sqrt{\pi} \sqrt{j \Delta t} \phi(x, y, j \Delta t) q(x, y, j \Delta t)\right]_{1}$

Applylng the trapezoldad rule to Ure cquation of $\left|K_{r}\right|_{1}$.

$\left[K_{1}=2 h_{1} \sum_{l=1}^{N I}\left(S_{1}+S_{1-1}\right)\right]_{1}$ 


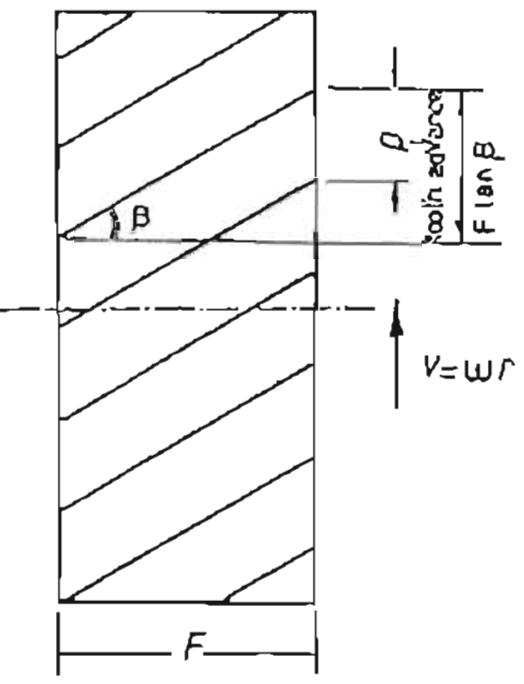

figl3_alContad ratio

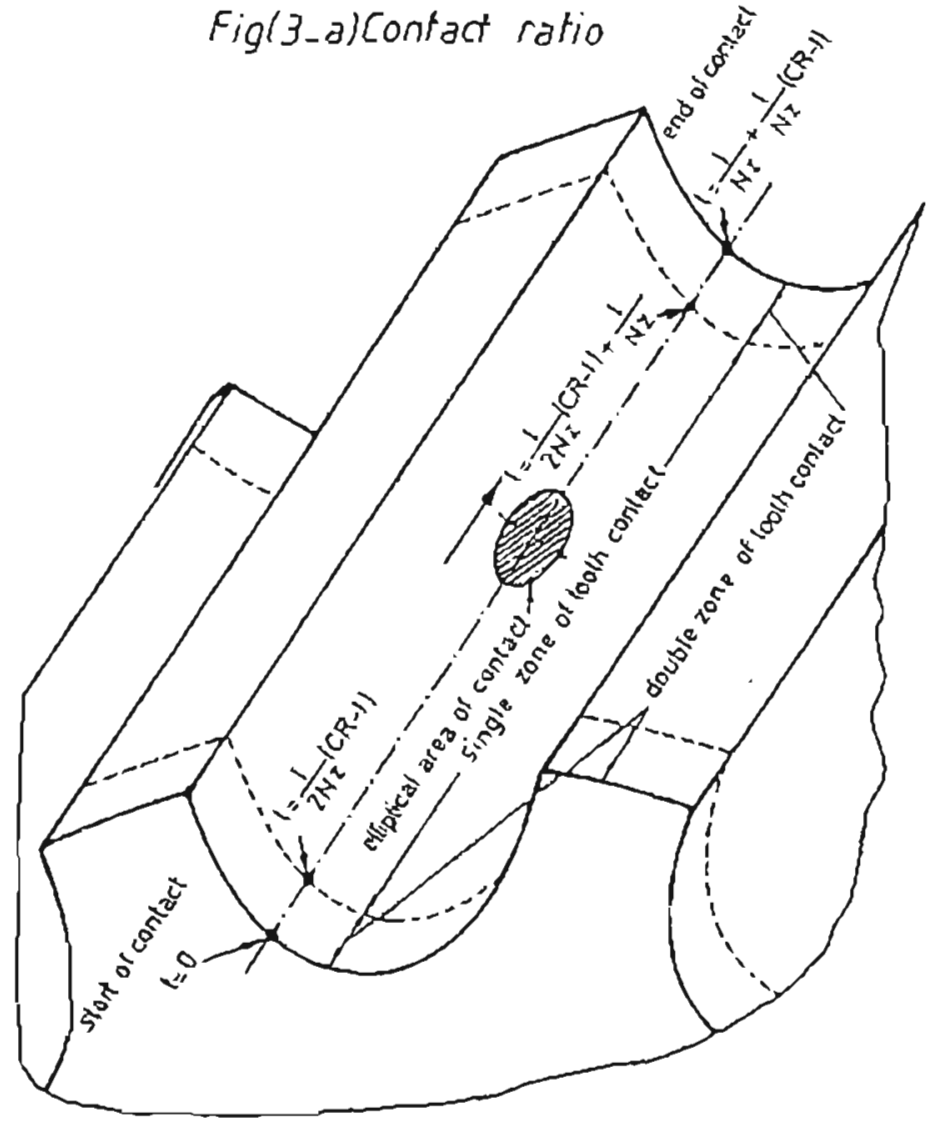

Fig(3) b) Time of mesting along the tooth face 
w) xerc

$\left[S_{l}=\int_{0}^{\xi_{u}} \sqrt{(j-r) \Delta l} \phi\left\{\tilde{x}_{1} \ln _{1},(j-r) \Delta t\right\} q\left\{\bar{x}_{,} \ln _{1},(j-r) \Delta l\right\} \exp \left\{-\left\langle\xi^{2}+\left(\operatorname{lh}_{1}\right)^{2}\right)\right\} d \xi_{5}\right]_{1}$

Nso applying the trapezoldal rule to the equalion of si

$\left[S_{1}=\frac{1}{2} h_{2} \sum_{m=1}^{N}\left(q_{m}+q_{m-1}\right)\right]_{1}$

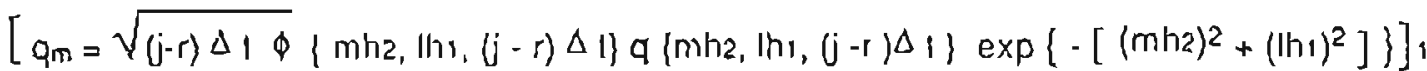

Similarly. for Uic wheel

$\theta_{2}\left(x^{\prime}, y, j \Delta l\right)=\left[\frac{2}{\pi y c} \sum_{r=1}^{i}\left(\left\langle K_{r-1}+K_{r}\right)(\sqrt{r \Delta l}-\sqrt{(r-1) \Delta l})\right\}\right]_{2}$

$\left[K_{r}=4 \int_{0}^{\xi_{u}} \int_{0}^{\eta_{u}} \sqrt{(j-r) \Delta l}\{1-\phi(\bar{x}, y,(j-r) \Delta l)\} q\left\{\hat{x}^{\prime}, y,(j-r) \Delta l\right\} \exp \left\{-\left(\xi^{2}+\eta^{2}\right)\right\} d \eta d \xi\right]_{2}$

$\left[K_{0}=4 \sqrt{\pi} \sqrt{j \Delta l}\left\{1-\phi\left(x^{\prime}, y,(j \Delta l)\right\} q\left(x_{1}, y_{1}, j \Delta\right)\right]_{2}\right.$

Applying the trapczoidal rule to the equation of $\mid \mathrm{Kr})_{2}$

$\left[K_{1}=2 \wedge \sum_{i=1}^{N_{1}}\left(S_{1}+S_{1-1}\right)\right]_{2}$

where

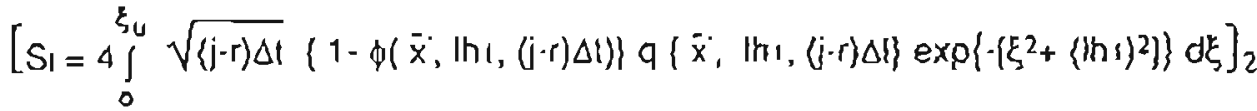

Also applyting the trapezoldal rule to the equation of $\left.|S|\right|_{2}$

$\left[S_{1}=\frac{1}{2} l_{12} \sum_{m=1}^{N 2}\left(q_{m}+q_{m-1}\right)\right]_{2}$

where

$\left.\left[q_{m}=\sqrt{(j-r) \Delta l}\left\{1-\phi\left(m h_{2}, I h 1,(j-r) \Delta l\right)\right\} q\{m h 2, I h 1,(j-r) \Delta l\} \exp \left\{-\left((m h 2\rangle^{2}+\langle| h_{1}\right)^{2}\right\}\right\}\right]_{2}$

From thesc cquallons and equalion (8). $\phi(x, y . j \Delta l)$ can be delemirned.

$A$ now chart of Uie calculations is shown in Fig (4). Thie loop corrcening $\mathrm{J}$ is for lue meshing Une, the loop concerning $M$ is for Ure position over the ellipteal area of contact along the looth face $x$-direction and loop $L$ concernung the second dincnsion of the elluplical area of contacl along the tooth height In $y$-direction. In the case of calculations $J=400 . M=50$ and $L=50$ to Insure a maxdmum accuracy. This work is proyranined will Fortran and nun on the v^x Compuler system under VMS opcralling system.

\section{THEORETICAL RESULTS AND DISCUSSION}

I- Ellect of Yoolh lood:

Fig (5) sliows the cliange of the nash temperalure divided by the coefticient of friction with the cliange of the applied tookh load at different runulng condisions and gerr varlables (spced, nodule.

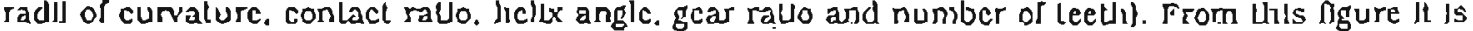
clearly sliown that the Mash tempcralure Increases wilh increase of the applled tooth load for all running conditions and gear varlables. It Is noticed that Usc quantily of Urc heal generated and lemperalure increased with increase of applicd looth load and (1)/s could be allributed to the lncrease or Herblan area of conlacl and conlact prcssure under load. This is indicaled in Fig (G).

A cunre fllung for these results has been found using Grapher Son ware iwhich glves bie following equation

$\theta / \mu=(0.01-0.177) P(0.802-0.979)$

Ranges of constants given in tils equation depend on the varlety of (Je ruming conditlons and gear varlables. The fiteing equalion for cac) curve is bidicaled In Fig (5). 


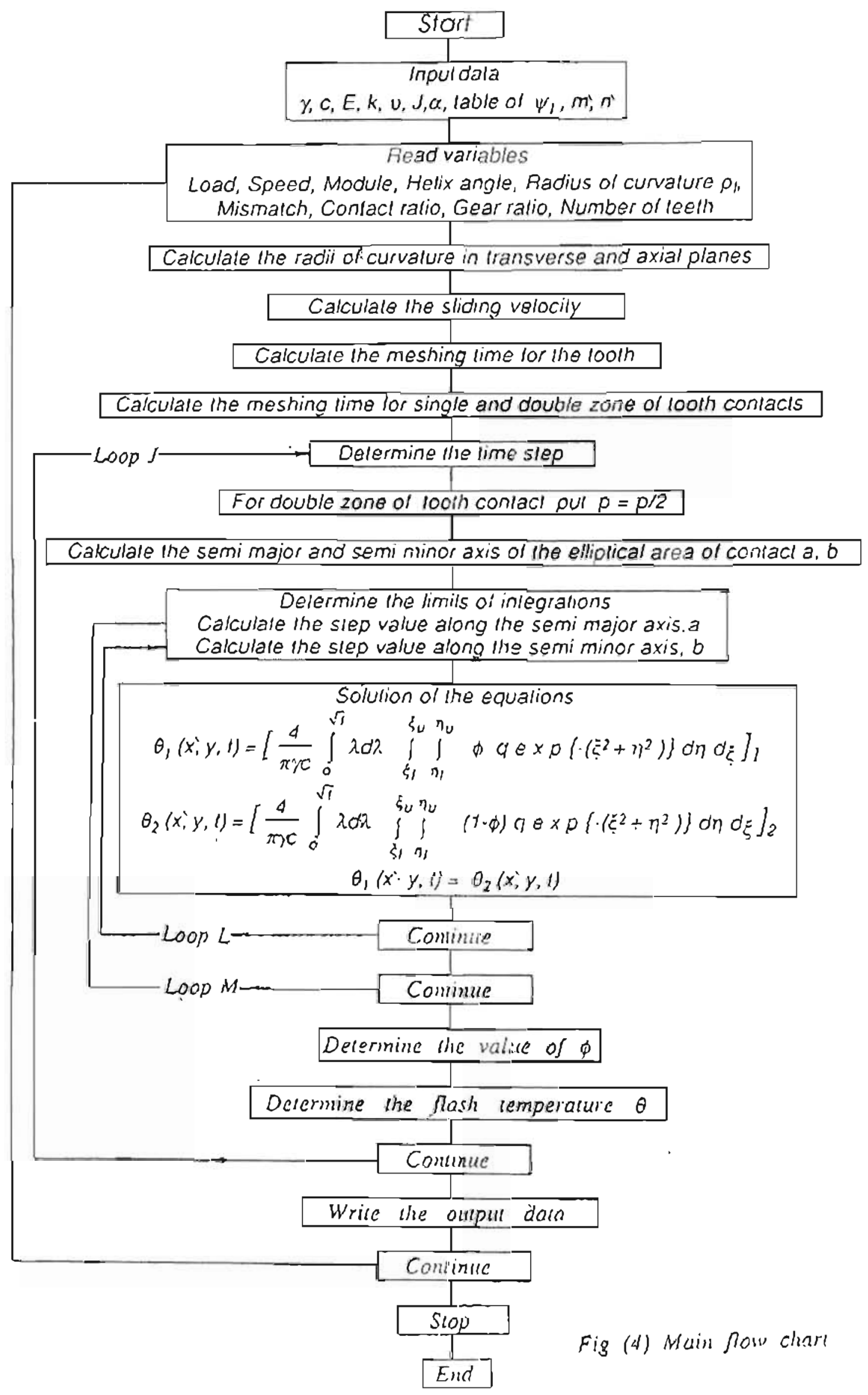




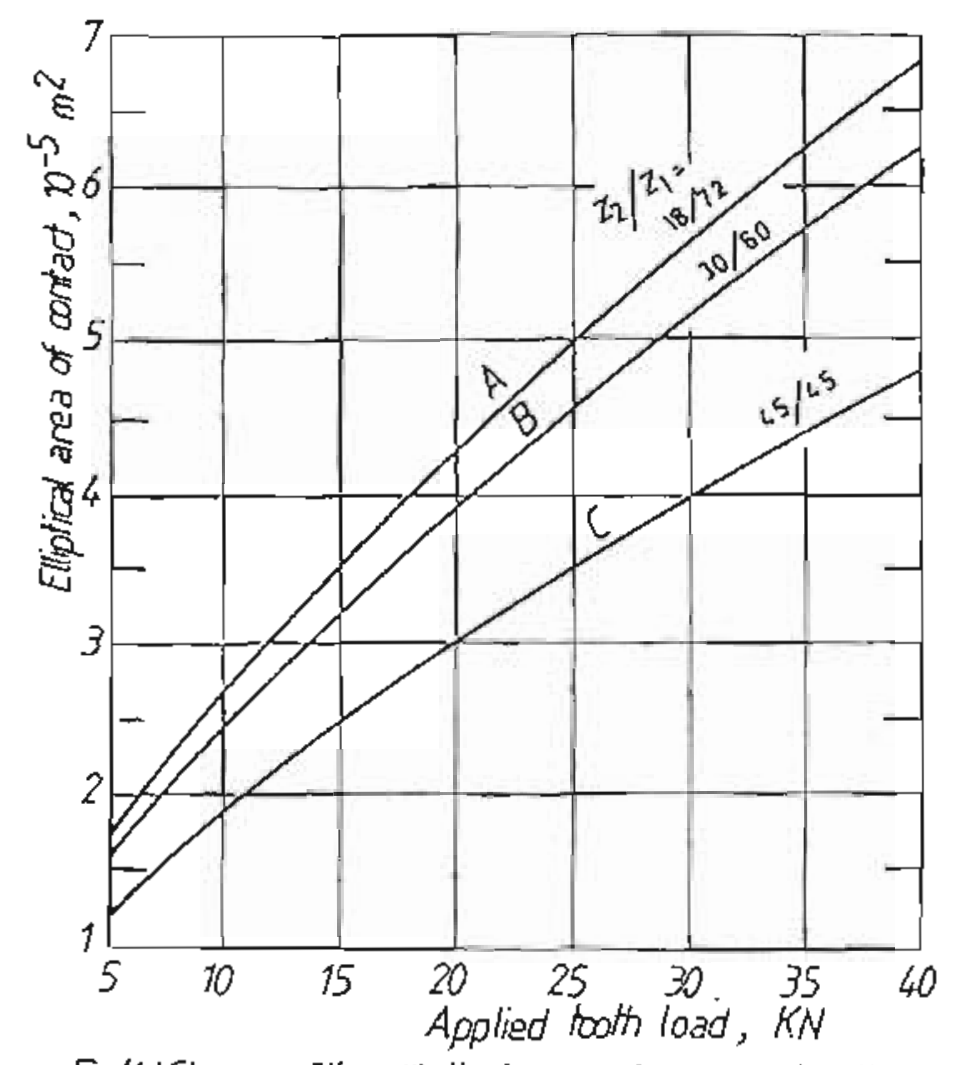

Fig(6) Change ofthe elliptical area of contact with the applied tooth laad for different gear variables

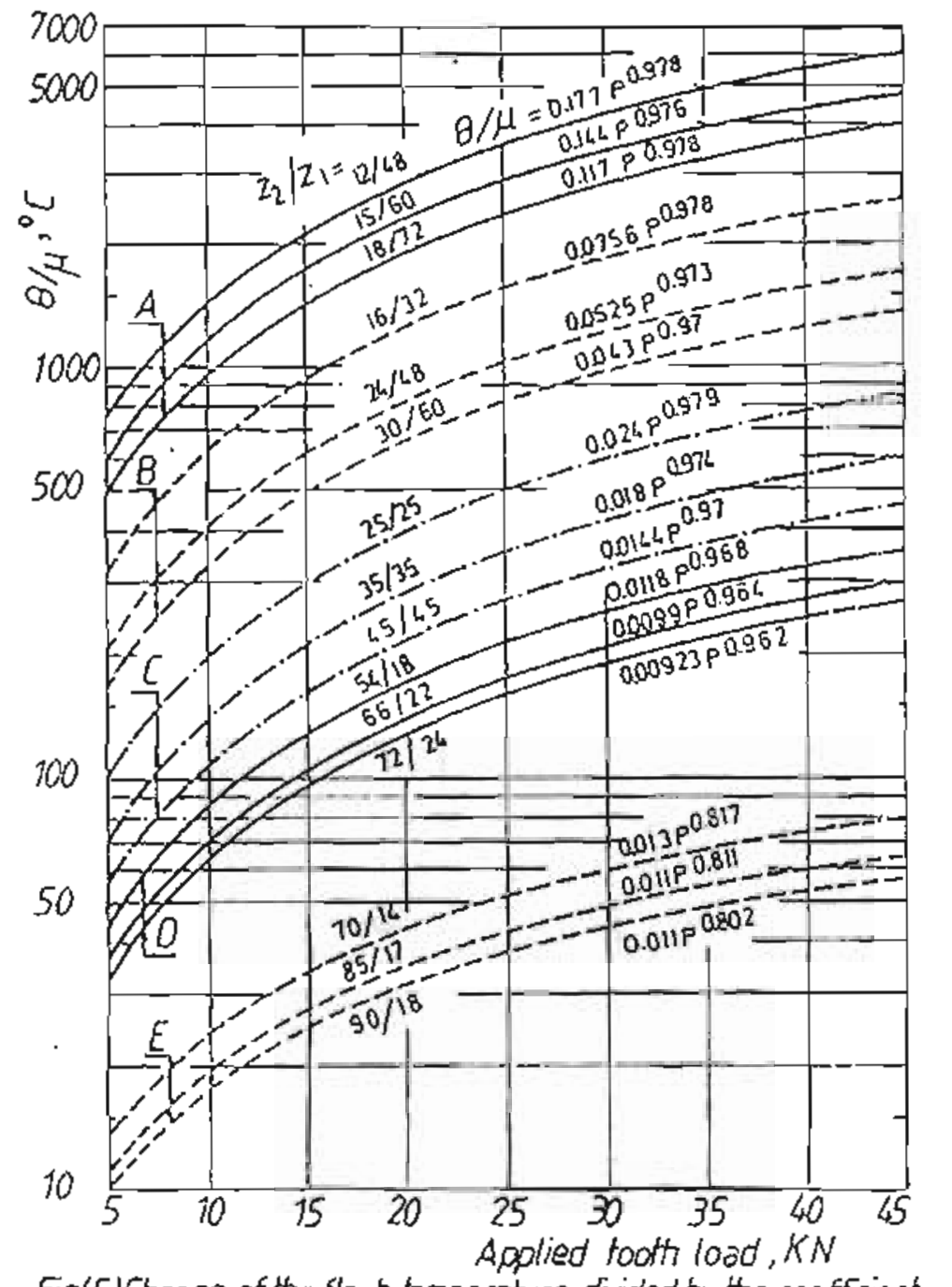

Figl(5) Change of the flash temperature divided by the coefficient of friction $(\theta / \mu$ ) with tooth load at different iming conditions and gear variables. Conditions. $A, B, C, D$ and $E$ see appendix $I$.

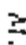




\section{Ellect of Specod of Rolalion:}

Fig (7) shows lie change of the nosh cemperature divided by the coemictent of filction wilh the change of the specd of rolallon al differchl rumning condluons and gear variables lloolh load. module radil of curvalure. helle angle. conlacl rallo. gear rallo and number of lecthi). Froin li,s

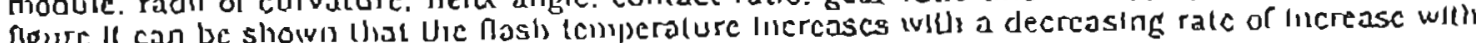
incsease of the specd of rolation. This coulc be expludncd as follows :

inilh the thcreasc of rolaung speed. Whe sllding velocliy incrcascs ivhich accordingly increases the amount of heal (cqualionl) and the Mash (cilperalure. On (he other hand, wllh tic increase of speed of rolation the (In) of conlact belween teeth along the path of tooth contact clccreases. wilch decreases the hash lempcralure.

. A curve lilting for these results has been found using Grapher solt ware and whlch gives the following equation

$\theta / \mu=(1.1-152.2) N(0.321-0.391)$

Ranges of constants glven in unis equation depend on lie varjely of the gear vartables and nunring conduluons. Thie litling equauon for each curve is indicaled in Figl(7) .

\section{3- Ellecl or Module :}

Fig (B) shows lie change or llie hash iemperature divided by the coemclent of finction with the cliange of tie module at duftcrent runding condilions and geas vartables. It is nouced that wh increase of module the nasli temperalure and the amount of heal lisererase for all running condiluons and gear variables. This may be due to lic lucreasc of Heralan contacl pressure and area of contacl Figig) (hcal generallon uncreases).

Curve rliung for the obtadned results was donc and the following relationshlp belween the Mash lemperalure divlded by the coefincical of friclion and Uic module bas been oblaticd.

$\theta / \mu=(1494-259172) m^{(0.8-0.979)}$

The ranges of constants in this equation depend on the variety of the running condluons and geas variables and the equation lor cach condition Is Indicated on (he approprialc curve shoivn in Fig(8).

\section{d-Eflecl of Helix Angle:}

Fig(10) shows the change of the fash lemperalure divlded by the coelisclent of frictlon ivith the clange of the helk angle al diferent nuning condusons and gear varlables. These curics show that Mash temperature sughlly Increascs wiUh licrcasc of the hellx angle of W/N circular are gear at all running condluons and gear varlables. Thils may be due lo the follolving:

With Increase of heltx angle the Ienglh of cooth facc Increascs, accompanied by an increase of accumulaled heal generallon and leinperalure due to increase of Lolal bme of mesh. On the other hand, wlth tncrcase of helle angle. lie Mertzlan conlace pressure and arca of conlact decreases as shown in Fig(11) which decreases llic heat gencration alid Uhe Hash teinpcralure. Accordingly, Uie nash temperalure slighlly Increases wlt) (he increase of the helle angle

A cunc filung for Lhese results has been found glving the following equallon

$\theta / \mu=(63.9-2463) \quad \beta(0.0619 \cdot 0.279)$

Ranges of constancs givell ill this equalion depend on the varlely of lisc gear varlables and the runilng condisuons. The nillng equation Tor each curve is Indicalcd in Fig( 10$)$.

\section{5- Effecl as Radius ol Curvalure:}

Fig(12) shows the change of the flash icmperolure divided oy lie coeffictent of friction with the change of the radius of curvalure of the pladon lools in the transverse plane for $\mathrm{W} / \mathrm{N}$ clrcular - are gears at dWerent running condillons ancl gear variables. It is very clear that lhe flash temperalure increases whth ulic increase of Uhe radlus of curvature. 'The rale of Increase is lilgh for the smaliest valuc of the radlus of curvature and decreascs with an Increasc of the radius of cunnture. This may be becausc. wilh increase of the radlus of cunalure of the pinlon tooth, all radil of curvalure of une pinton and whecl teelh incrcase, dimensions of the toodt incrcase, and the contzed pressure and Herbian area of contacl increase as sliown in Figld3). Accordingly. the quantily of the heat gencrallon and Uie nash temperalure Increase.

Curve fikung for the oblalned sesults was done and the following cqualion was obianed

$\theta / \mu=(1322-39710) p^{(0.735-1)}$

The ranges of constants in thls equalion depend on the vanely of (he running condluowi and gear vartables and the equauon for each condlion is indicaled al ils allollcd curec shown lig Figl 12 . 


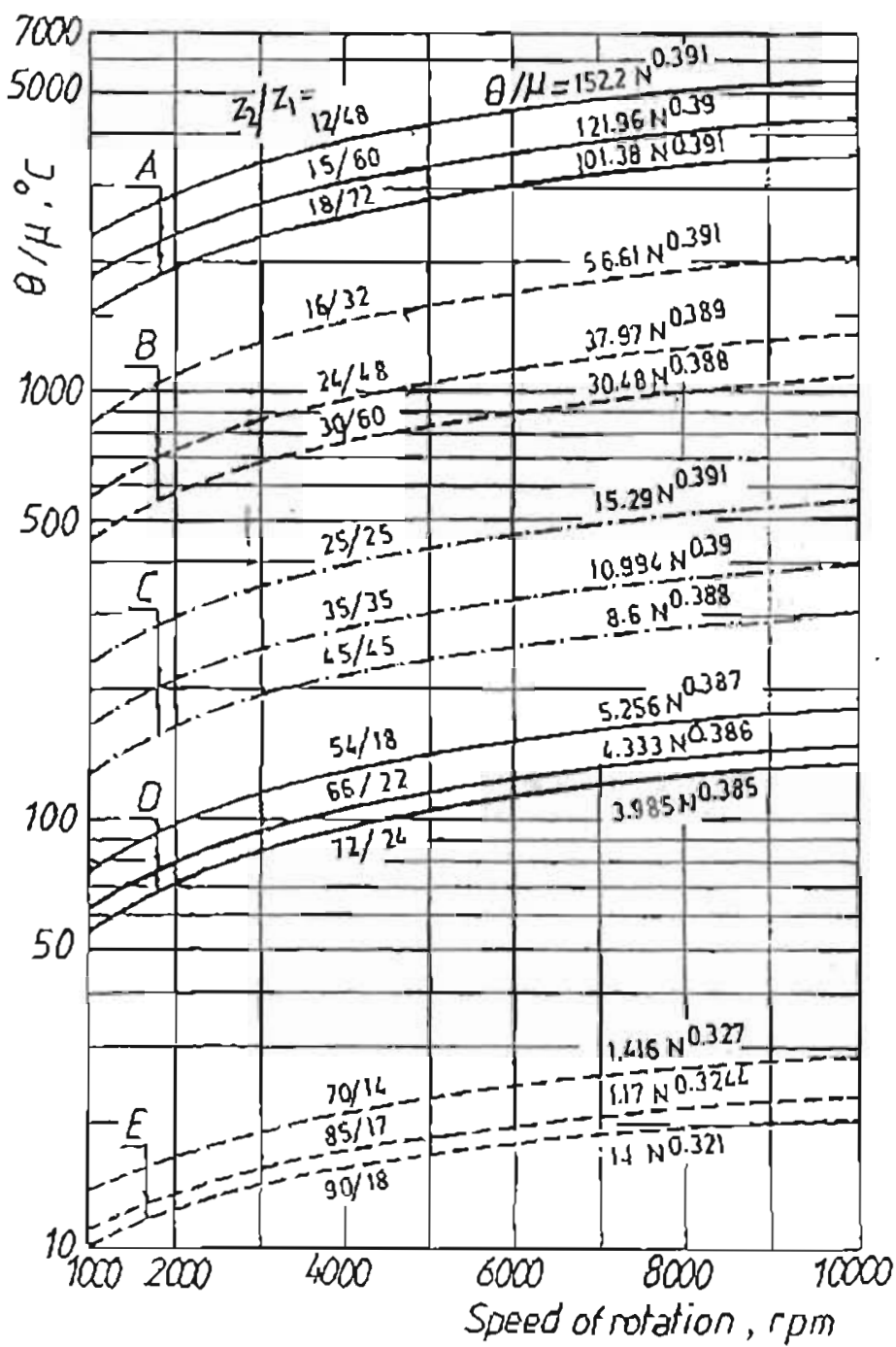

Figl 7)Change of the flash temperature divided by the coefficient of friction $(\theta / \mu)$ with speed of rotation at different ruming conditions and gear variables.

Condilions $A, 8, C, O$ arde ore given in appendix । 


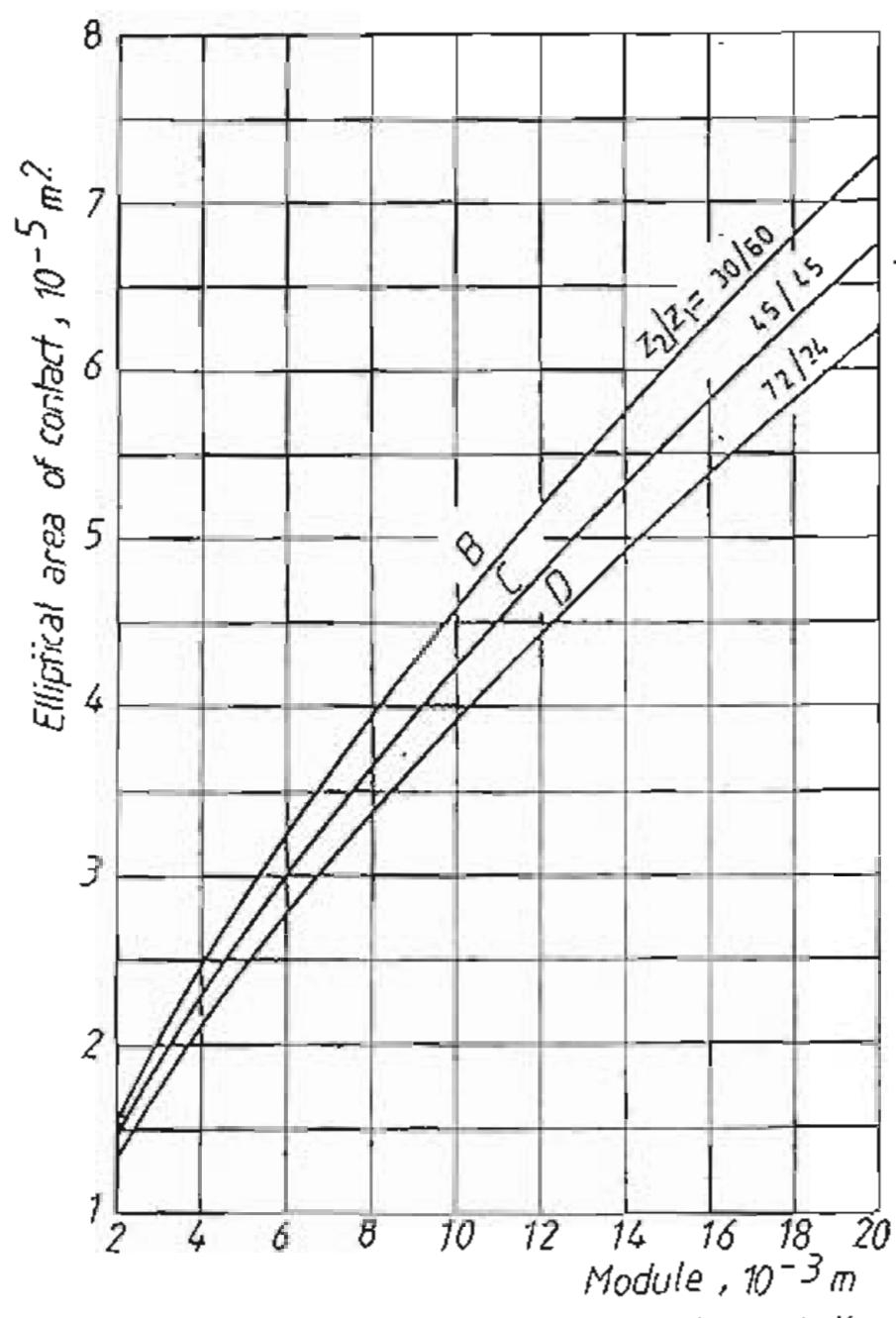

Fig(9) Change of the elliptical area of contact with the module at different runing conditions.

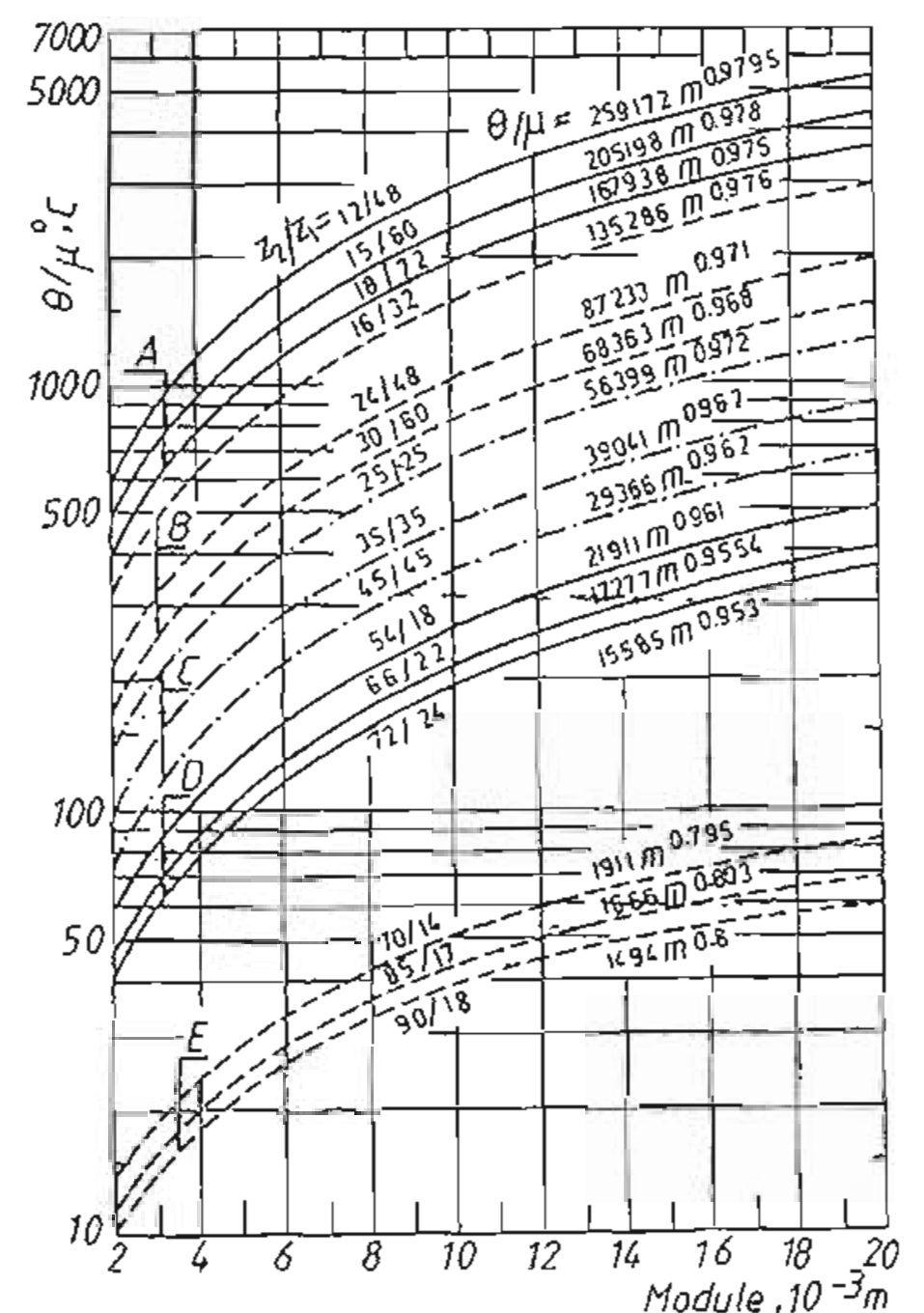

Fig(8)Change of the flash temperahre dinded by the coet ficient of friction with the module at differentruning condihions and gear variables. Conszlins A, B.c.,E, are given in appendix I 


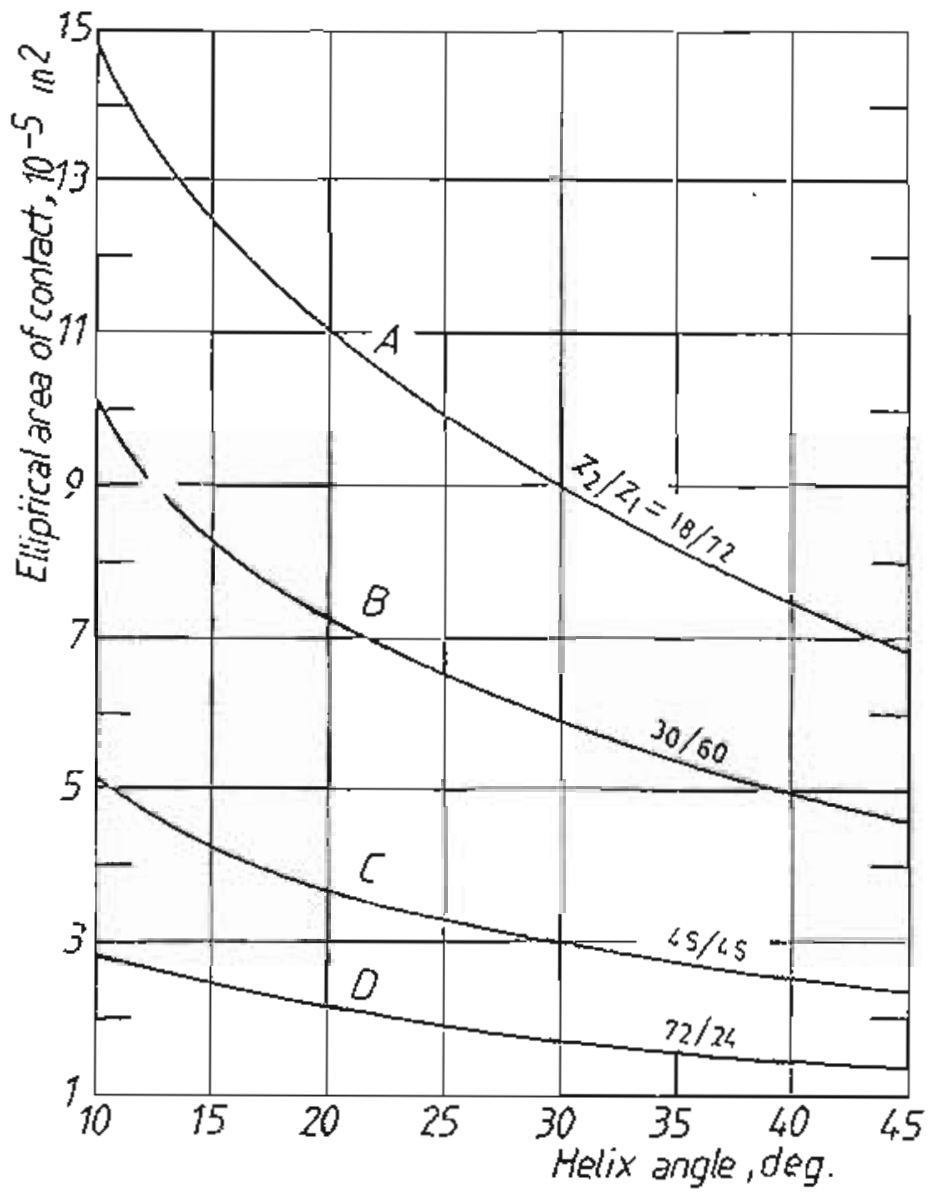

Fig(11)Change of the elliphical area of contad with the helix angle atdifferent running conditions.

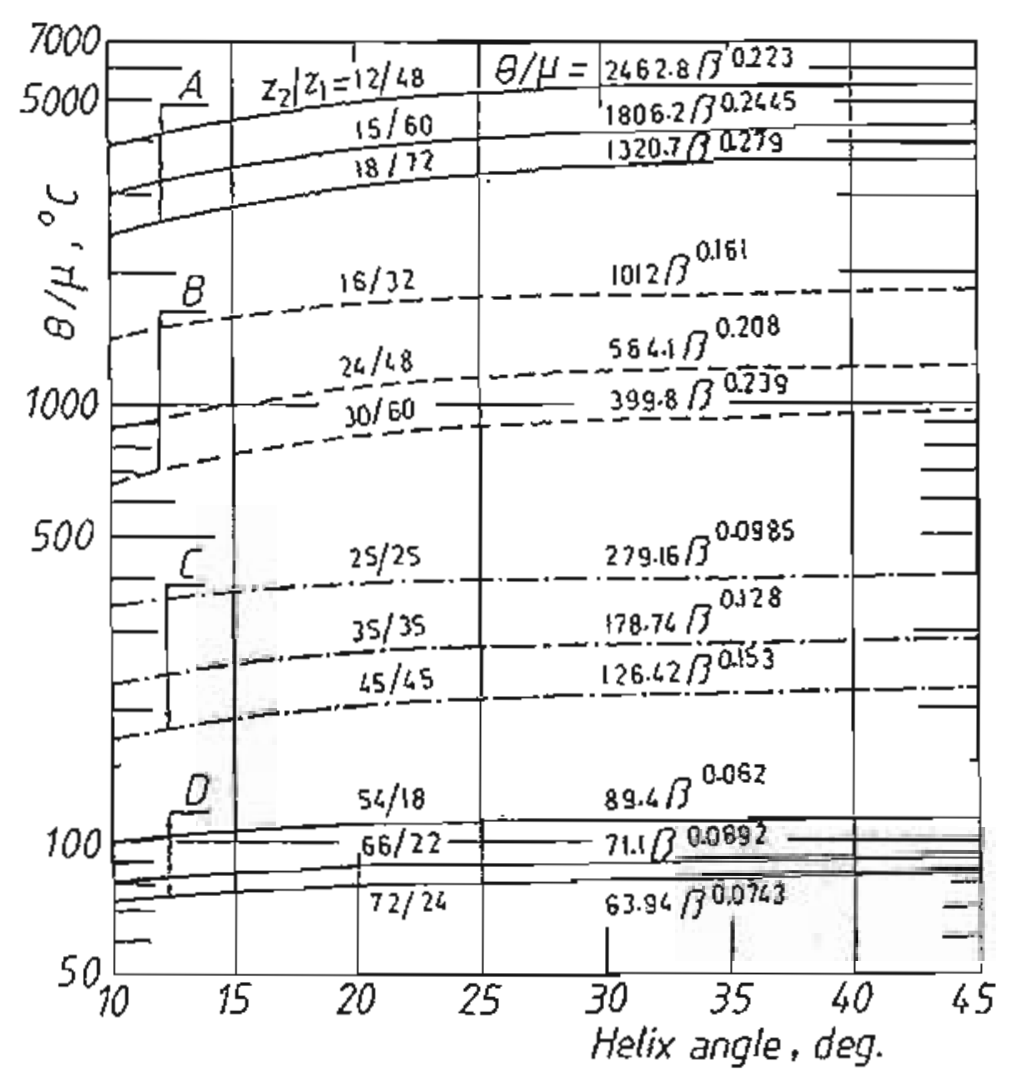

Figl10) Change of the flash temperature dinded by the coefficient of friction $(\theta / \mu)$ with the helix angle at differentrum ing conditions and gear variables. Conditions $A, B, C$ and $D$ are given in appendix 1 . 


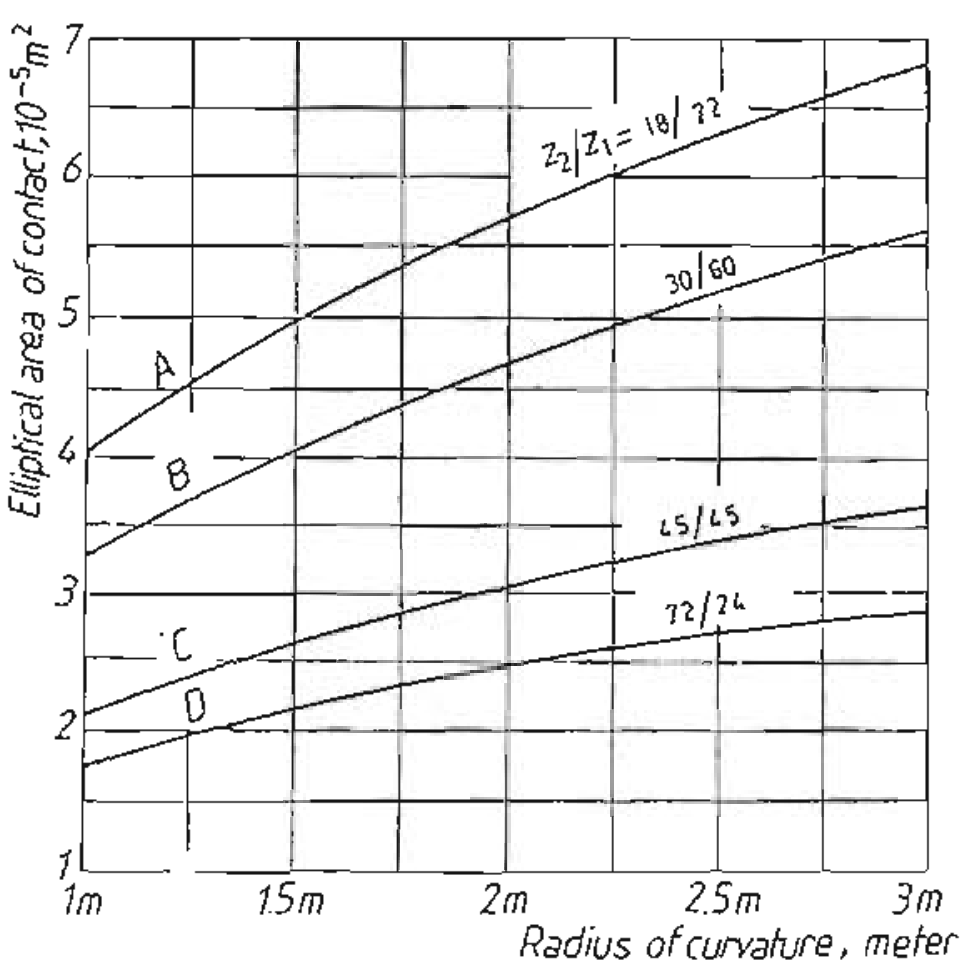

Fig (13) Change of the elliptical area of contact with the radius of curvature of the pinion tooth at different running condihions.

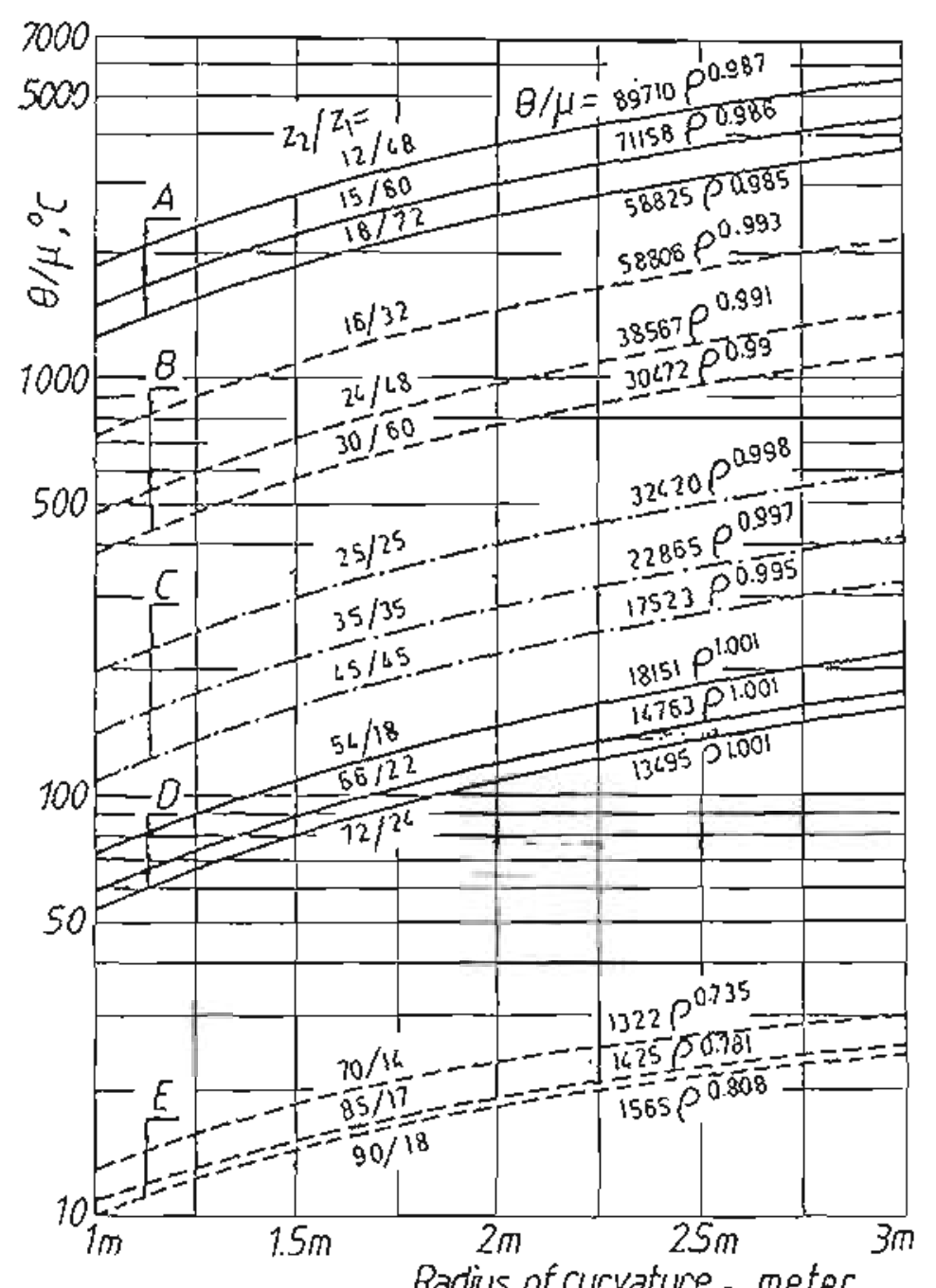

Figh l lhange of the flash temperature divided by the coeffxi ent of friction $(\theta / \mu)$ with the radius of arvature of the pinion

tooth at different ruming conditions and gear variables. Condilions A, $E . C . D$ and $E$ are given in appentix 1 


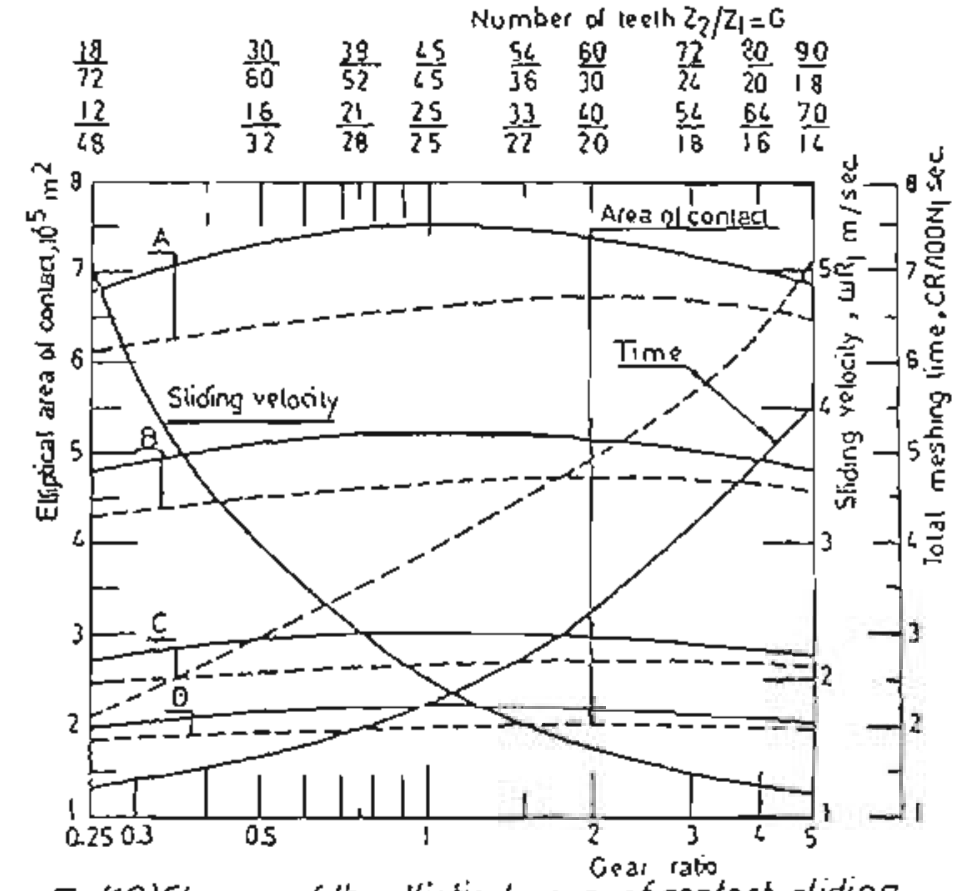

Fig(15)Change of the elliphical area of contact, sliding velocity and total meshing time with the gear ratio aldifrerent ruming conditions.

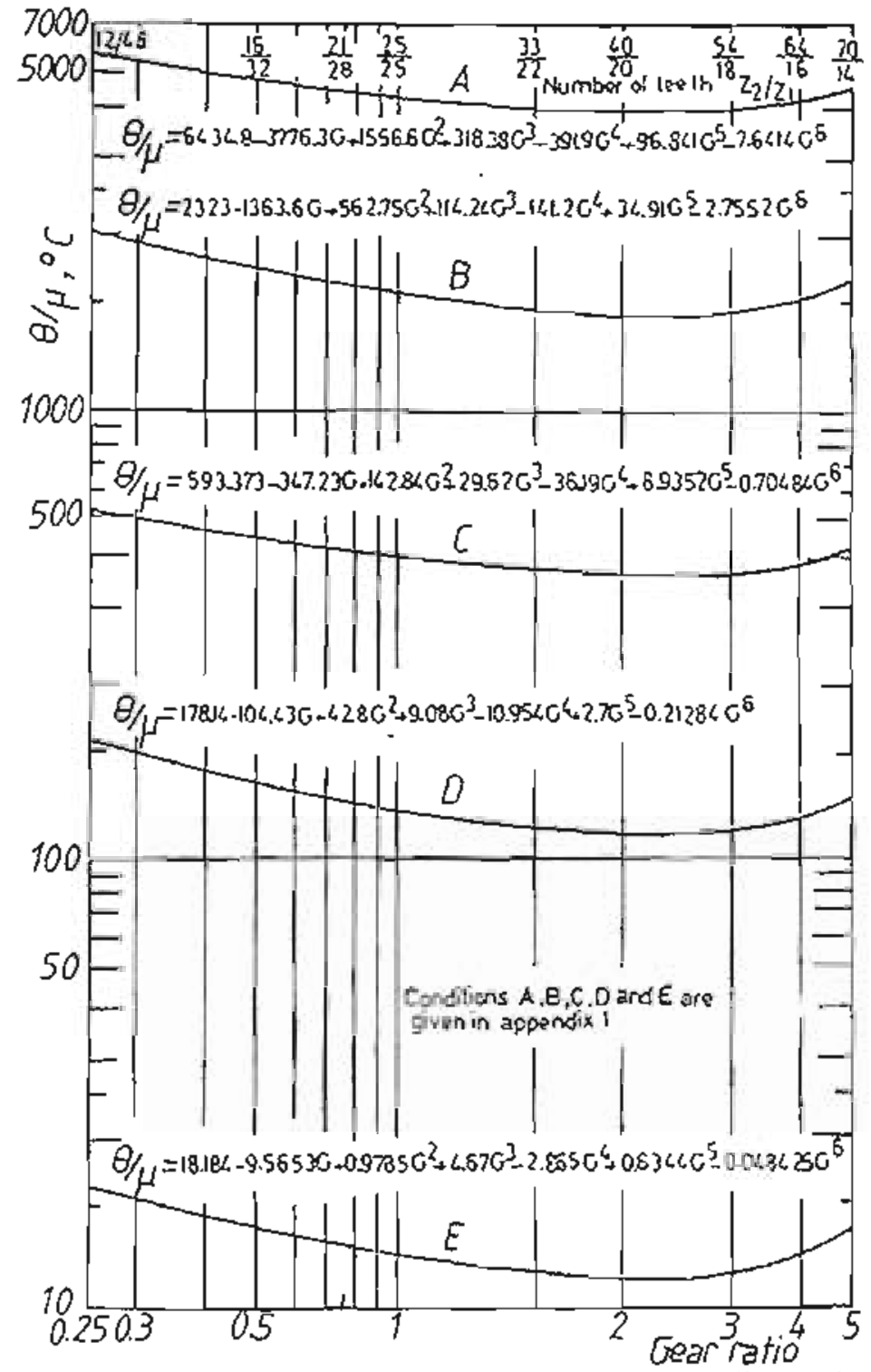

Figl/4 clChange of the flash temperature divided by the coet. ficient of friction $(\omega / \mu)$ with the gear ratio at differentrunning conditions. 


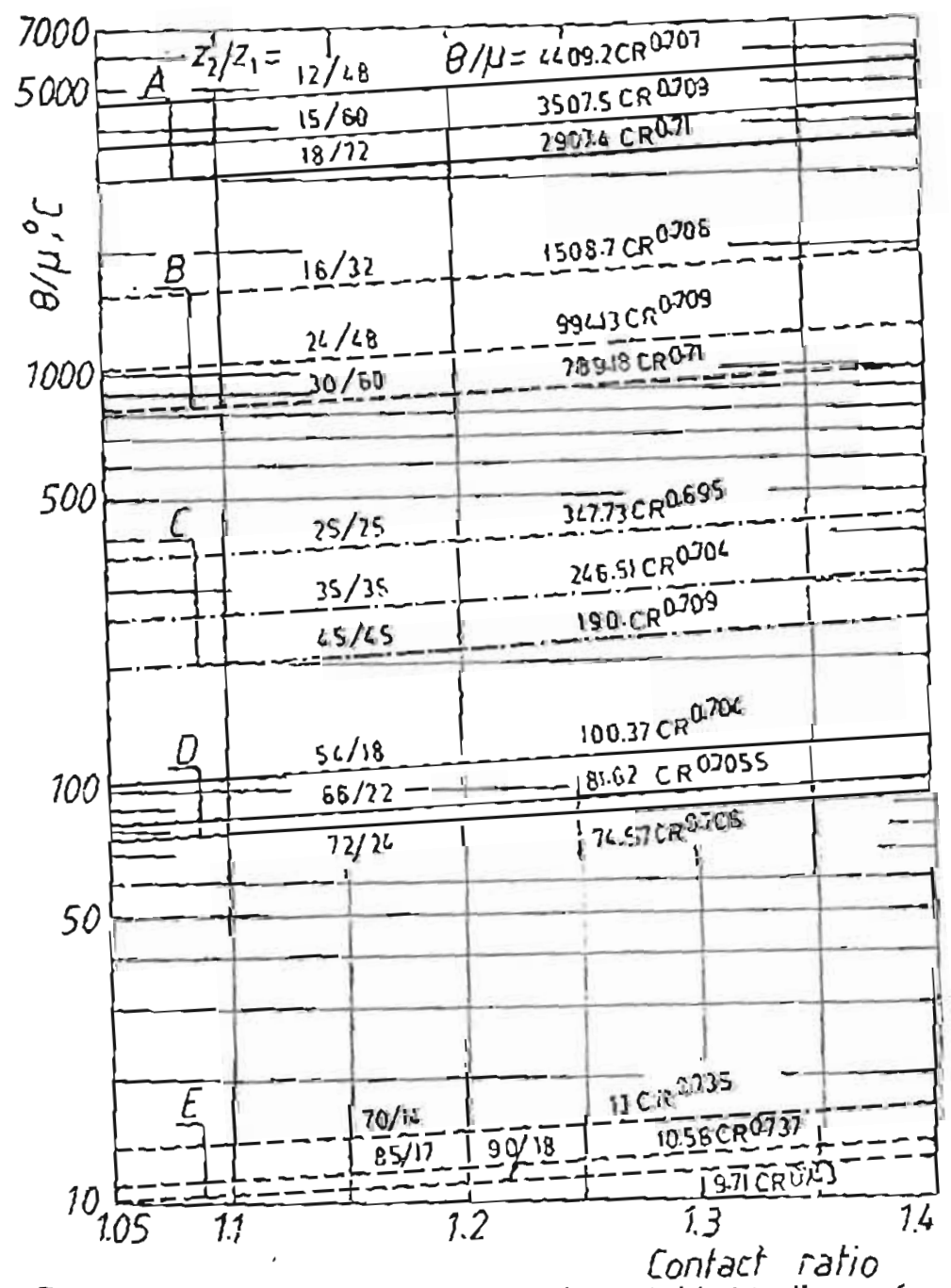

Figlic) Change of the flash hemperature divided by the coef. ficient of friction $(\theta / \mu)$ with ihe contact ratio at differenl gear variables and running conditions. Conditions $A, B, C, D$ and $E$ are given in appendix 1 
Complete form of the hash temperature equatlon was cleriven. This equalion contalns applised

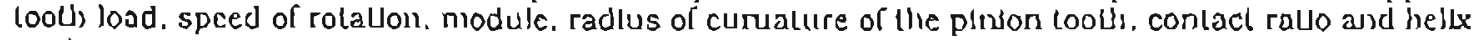
angle.

$\theta / \mu=C D 0.9725 \cdot N 0.389 \cdot m^{0.968} \cdot \rho^{0.994} \cdot C R 0.706 \cdot 180.193$

\section{REFERENCES}

Archard. J. F.. "The Teinperature of Ruljbing Surlaces," IVIAR Vol.2, 1958/59. pp.438-455.

Blok.H., Theorellcal Study of Tcmperalure Rse al Surfaces of Aclual Conlacl under Olliness Lubricaling Conditions." Proceedings of the General Discussion on LUBRICATION AND LUBRICANTS. Institution of Mechanlcal Engineers, Vol.2, 1937, rp.222-235.

Bowder, F. P. and Tabor, D.. "The Frlelion and Lubricalion of Sollds," Odford Universliy Press. Jondon, 1950.

Cherey. W. and Klncald. D., "Numerical Mathemalses and Compu-ting " Books / Cole Publishlng Company. Monterey, Califorma, 1980.

Dysor, $\Lambda$, Evans, b. P. and Snlullc, R. w., "Wudlsaber-Novthou Clrcular Ne Gesrs: Geometry and Kinemaues" Proc.R Soc. Lond. A Vol.. 403. pp 313-310. 1986.

Gerald, C. F., - Applied Numerical Analysis. "Addison-Wesley Publishing Company. Singapore. 1978.

Holm, K., "Calculaton of (he tempertaurc Developruent in a Contact Surface and Applicausn to Uic problem of the Temperalure Rise in a Sliding Cantact." JOURNAL OF APPLIED PFIYSICS. Val. 19. No. 4. 1948. pp. $361-366$.

Jacger, J. C." "Moving Sources of Heat and Temiperature at Sliding Cantacts." Proccedings of ROYNL SOCIETY OF NEW SOUTH WNLES, Vol.56.1912.pp. 203-224.

Nakada. T. and Fashimoto. 8. "Heal Conducllon lin a Senv- Inflnlle Solid Hented by Moving Soure Along the Bourdary." Bullellin of JSME. Vol.,6. No. 21, 1963. pp. 59-69.

Roark, R. J., "Formulas for Stress and Staun" FourU) Ediuon. MCGrau. MU Book Co.. 1965.

Roylance. B. J. and ALKateb, $\Lambda$. M.." Further Developmenis in Conlacl Temperalure Delcmination in Four-Ball Machlne Operaulan and Uhe Trlbologlcal Inipllcabons." I. Mech. E. C 170/87.1987, pp.399-410

Symm. G., T.. "Surface Temperature of Two Rubbing Bolles." Quarlerly JOURNAL OF MECHANICS AND APPLIED MATHEMATICS Vol., 20, Pl.3, 1967. pp.381-391.

Tcrauchl, Y.. and Morl, Ir., "Comparison of Lheories and experimenial results for Surfaco Tcmperalure of Spur Gear Tecth." Trans. ASME. Joumal of Englnecrlng for hindusiry. Sebruary. 1974. pp. $41-50$

Timoshenko. S. P. and Goodlcr, J. N. "Theory of Elastlclty" Tilrd Edllion, Mc Graw- Hull Book Company. J 984 .

Tobc. T. and Kato. M., "A Study on Plash lemperalures on the spur gcar tecth," Trans. ASME Joumal of Englneering for industry. Februayy. 1971. pp.78-81.

\section{APPENDIX 1}

\section{Value of the Constant " $\mathrm{C}$ " in the rlash Temperature cquation}

\begin{tabular}{|c|c|c|c|c|c|c|c|c|c|}
\hline \multicolumn{2}{|c|}{ Condicion $A$} & \multicolumn{2}{|c|}{ Condilion B } & \multicolumn{2}{|c|}{ Condilinu $\mathrm{C}$} & \multicolumn{2}{|c|}{ Contelilion D } & \multicolumn{2}{|c|}{ Conduition $\mathrm{E}$} \\
\hline $\begin{aligned} G & =0.25 \\
& =Z_{2} Z_{1}\end{aligned}$ & C & $\begin{aligned} G & =0.5 \\
& =Z_{2} R_{1}\end{aligned}$ & $c$ & $\begin{aligned} G & =1 \\
& =z_{2} R_{1}\end{aligned}$ & C & $\begin{aligned} G & =3 \\
& =z_{2} z_{1}\end{aligned}$ & C & $\begin{array}{l}G=5 \\
=2_{2} r_{1}\end{array}$ & C \\
\hline $12 / 48$ & 1.428 & $1 6 \longdiv { 3 2 }$ & 2.497 & $25 / 25$ & 5.405 & $5 / / 18$ & 9.444 & $70 / 11$ & 25.0 \\
\hline $15 / 60$ & 1.137 & $24 / 48$ & 1.649 & $35 / 35$ & 3.824 & $.60 / 22$ & 7.675 & $85 / 17$ & 20.43 \\
\hline $18 \pi 2$ & 0.9434 & $30 / 60$ & 1.31 & $45 / 45$ & 2.919 & $72 / 24$ & 3.0141 & $90 / 18$ & 18.84 \\
\hline
\end{tabular}

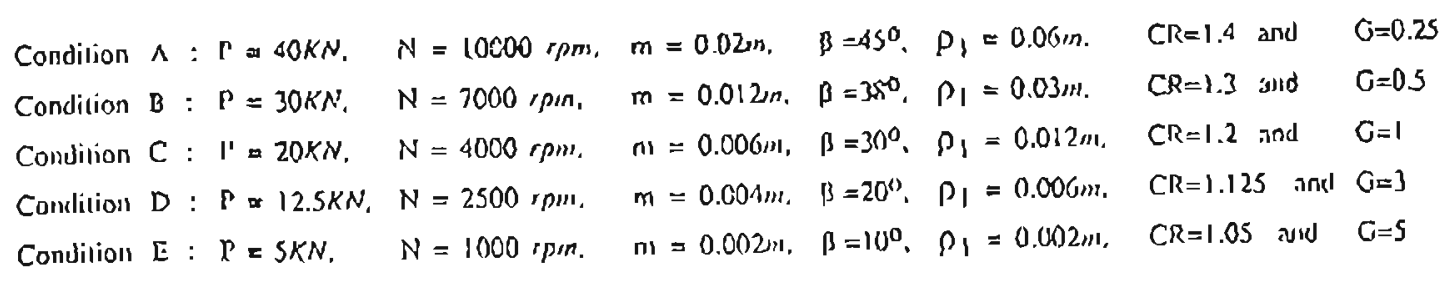

